\title{
Shooting Gaza: Israel's visual war
}

\section{$\underline{\text { Abstract }}$}

In this paper I show how the imaging and representation of war is becoming ever more central to its conduct: warfare is being fought through what I call 'image-fare'. I focus on the 23-day war on Gaza that began on the $27^{\text {th }}$ December 2008, and make four interconnected claims about the relationship between visuality, law and violence. First, the strategic use of images by the Israeli military in Gaza served a legitimizing function that positions Israel as always and already the lawful victim, scripting Hamas as terroristic perpetrators, belonging to a resolutely "hostile" space (i.e. Gaza). Second, these visualities 'work' via the appeal to the immediacy of images; Israel insists on the factual, and thus legal, veracity of its own visual forms while rendering their - Palestinian - visual forms voyeuristic and intrinsically biased. Third, contesting these visualities and exposing the inconsistencies of the Israeli framing is difficult when taking into account the ways in which the visual fields of war are structured by 'visual economies' which regulate and mediate global media, and which construct new publics in the process of doing so. Wary of overstating the power of Israeli framings, while understating the possibilities of challenging those framings, I finish by considering what role the circulation of the visual archive might have in challenging Israeli visualities.

Keywords: Gaza; Israel; war; lawfare; visuality

Craig Jones, the University of British Columbia, Vancouver

Gaza's visual fields

On the $27^{\text {th }}$ December 2008 Israel launched 'Operation Cast-Lead', a fully-fledged military attack upon the Gaza Strip. Weeks earlier, on November $4^{\text {th }}$, the Israeli Defence Force (IDF) instituted a ban on the entry of foreign journalists into Gaza. The ban was not eased until after the fighting had 'stopped' three weeks later when Israel finally declared a ceasefire. Foreign press could not gain access to Gaza so the IDF stationed them beyond the 'closed military zone' two kilometres away from the action atop Parash Hill, a tourist spot above the Israeli town of Sderot. But why would the IDF ban journalists from Gaza, and why did it allow them to cover the asault from a hilltop? If the aim was to stop sensitive and potentially damaging images from being seen then the ban failed miserably: Death and destruction were photographed and filmed extensively by the Palestinian journalists already in Gaza - and these images were published in the international press. But what if the aim was never to stop images from getting out? What if, 
as David Campbell (forthcoming) has argued, the aim was not about prohibiting the circulation of images but rather permitting the circulation of some while politicizing others as inevitably biased?

In her last book, Regarding the pain of others, Susan Sontag drew attention to the longstanding relationship between photography and modern war. Sontag may not have been the first to suggest that modern war is waged with images but her work demonstrated that the connection has become definitive: If we are going to talk about war then we have to talk about the presentation and representation of war. Sontag was primarily concerned with photographs but today the visual fields of war are structured by new and multiple forms of visual media. Governments now have their own Youtube channels; key figured of politics and the military have become Facebook and Twitter fanatics; embedded journalists are attached to militaries on the front lines and war can now be witnessed from the perspective of a missile as it whistles toward its victims. These new visual media mean that audiences are experiencing and witnessing war in complex and diversifying ways, but the turn toward the visual (see Macdonald et al 2010; Campbell 2007) also produces and constitutes these audiences and publics in the process.

Today the visual frames and discourses of modern war are being recruited to mandate a field of perceptibility which impels publics toward certain apprehensions of war. These frames build an interpretation that according to Judith Butler (2009: 100) "constrains what can be heard, read, seen, felt and known". And so at stake in the mandating of perspective is the very ontology of war, forcing us to ask: what and whose account will count as 'real'? The state, Judith Butler (2009: 66) claims, has an "orchestrative power" to ratify what will be called reality and we have recently witnessed, in both Israel and the U.S., a concerted effort to regulate the visual field to do just this. But framing and regulating are not only concerned with the visible and the invisible but 
their constitutive relation, not what is seen but how what is seen. These are not theoretical precepts: A powerful visual and discursive framing of war is currently taking place around what are being called the 'new wars' (see Kaldor 2006; Münkler 2005). The new wars discourse delineates a Manichean geography between the way that states and non-state (or pre-state) actors fight war. As Derek Gregory (2010: 266) has pointed out, advanced militaries go to great lengths to represent their own operations as "surgical, sensitive and scrupulous" and this turn toward 'clean war' is part of what Christopher Coker (2004) has called the "re-enchantment of war". But as Gregory insists, it is only 'our' wars that are re-enchanted. The same militaries that insist on the humaneness of 'our' wars direct public attention to an enemy which is "indiscriminate, insensitive and illegitimate" (pp. 267). These broader frames of war intersect closely with Israel's ${ }^{1}$ framing of Gaza.

In this paper I show how the imaging and representation of war is becoming ever more central to its conduct: warfare is being fought through what I call 'image-fare'. Using Israel's ban on international media as a focal point, I make four interconnected claims. First, Israel's strategic use of images helped to legitimise the assault on Gaza. Two framing devices were essential: First, Israeli visualities construct Israel as victim. Second, the designation of Gaza as a 'hostile entity' prefigures Gaza and Hamas as the perpetrator.

\footnotetext{
${ }^{1}$ The use of 'Israel' and 'Israeli' denotes a collective and requires justification. I recognise that 'Israel' has many different meanings across many different people and understand that not all Israeli's share the same opinion and ideas about how the state of Israel conducts its activities. I acknowledge an internal Israeli politics and give voice to the marginal (but perhaps growing) dissenting voices in spaces such as: the academy; the boycott; journalism (especially Haaretz); the army (especially Breaking the Silence); the anti-occupation movement; activist politics and exile. It is critical to acknowledge that while there is a critical Left in Israel, the overwhelming political attitude supports the status quo of Occupation and has done so for a long time. While the 'Israeli' narrative is therefore concerned with Israeli politics, it is also necessarily much more than capital 'P' Politics. As Eyal Weizmann (2008) has pointed, out there exists a statist imaginary within Israeli society; the line between official and non-official scripts, between public and private is increasingly blurred. While not without problem, 'Israel' and 'Israeli' are useful descriptive categories that capture a dominant (albeit complex and heterogeneous) set of assumptions.
} 
Second, the Israeli narrative appeals to the immediacy of images, insisting on the factual, and thus legal, veracity of the visual form, or rather, its own visual forms. Israel implores international audiences to see what they believe when it comes to showing Israel as victim or Hamas as terroristic. Seeing is unmediated, Israel claims: images speak the truth. These visualities are then used to make and substantiate a series of legal claims about the enemy. These claims reproduce Gaza as a lawless space while depicting Israel as law-abiding - and again a clear victim and perpetrator are availed.

Third, Palestinian footage and images of death and suffering must not be interpreted as necessarily effective in contesting the visualities of war deployed by Israel. Israel's decision to ban journalists was based on the assumption that it could control what was seen and known of the assault on Gaza and yet ironically Israel ended up ensuring that international audiences saw more Palestinian coverage than ever before. However, the visual fields of Gaza are much more complex than reading one set of images against another: Palestinian visualities cannot simply be taken as necessarily 'countering' anything merely because they are Palestinian. Taking serious the notion that images work within what Deborah Poole and David Campbell have called the 'visual economy' I focus on the ways in which ostensibly critical visualizations of Gaza were blunted by three 'economies of regulation'. First, international press edit and censor suffering and death in the name of 'taste and decency'. Second, 'balanced' reporting has meant that Palestinian suffering was often represented alongside Israeli suffering, drawing a problematic moral and political equivalence between the two. Finally, the pictoral coverage of Gaza ends up producing the assault as a temporary humanitarian catastrophe rather than a political episode of carefully planned and orchestrated violence. 
Wary of overstating the power of Israeli framings while understating the possibilities of challenging those framings, I finish by considering what role the circulation of the visual archive might have in challenging Israeli and IDF visualities.

\section{Hasbara}

Israel's blanket media ban was never about the suppression of "truth"; rather, it was a way of organizing and disciplining the gaze of the international community so that some things could be seen while others remained hidden from view. The ban was not therefore an attempt to "keep Gaza hidden" David Campbell (forthcoming: 10) has argued, "it was an attempt to politicise the hundreds of pictures that emerged daily as inevitably "biased"'. Limiting the availability of images was part of a wider effort to produce a particular visualization of the conflict. It was not incidental that the international media covered the assault from the hills of Sdreot. As Ariella Azoulay (2009) argues, the position helped construct a particular war: "From their observation point, what they see is exactly the picture that Israel wishes to show: a war fought on equal footing by two sides. Missiles launched in Gaza hit Israel, and Israel retaliates." This imaging levels the asymmetries of the conflict, but the distant positioning of the cameras also works to elide the death and suffering beneath and after the smoke and bombs that so resemble the 'shock and awe' doctrine. The camera at distance, just like the view through the scope of the aerial targeting device, erases bodies from the landscape of war, or as Lillie Chouliaraki (2009: 225) has put it, "Western media broadcast from positions of showing that exclude the witnessing of human death and render the reporting of this war an exercise in military action". The media ban disciplined our gaze, instructing us not only what to see, but compelling us how to see what we see. 


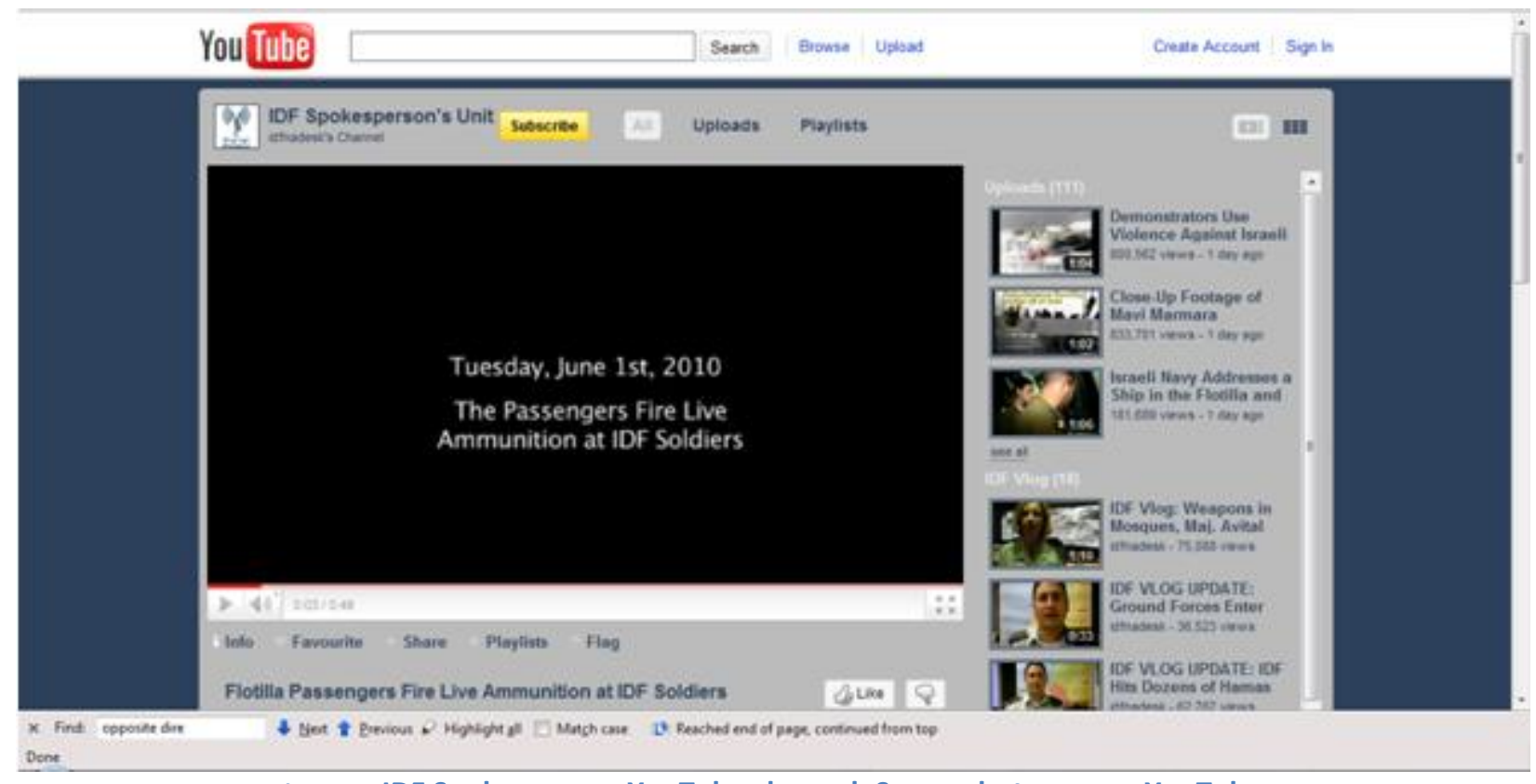

Figure 1. IDF Spokesperson YouTube channel. Screenshot, source: YouTube

Once the ban was in place the National Information Directorate (NID) ${ }^{2}$ was tasked with explaining Israel's position to the world. The word for explanation in Hebrew is "hasbara", but pejoratively it also means spin and propaganda (Shabi 2009). The directorate's chief, Yarden Vatikai, pointed out that the "hasbara apparatus needed a body that would coordinate its agencies, coordinate the messages and become a platform for cooperation between all the agencies that deal with communication relations and public diplomacy" (quoted in Shabi 2009). The internet and the new/social media were an essential component of the hasbara campaign and as soon as the first bombs were dropped, the IDF Spokesperson Unit (IDF-SU) launched its own YouTube channel (figure 1). The channel was set up to detail "the IDF's humane action and operational success in Operation Cast Lead" (IDF 2009) and it soon became the most subscribed

\footnotetext{
${ }^{2}$ The NID was established in 2007 at the recommendation of the Winograd Comission, a commission headed by Eliyahu Winograd with the mandate to investigate the events that took place in (and leading upto) the 2006 Lebanon war. The main findings were published in an interim report in April 2007, followed by a final report which was published in January 2008 (MFA 2008). One of the key recommendations of the report was that the IDF should put more effort into PR. The NID was established as a corrective to the IDF failures in Lebanon in 2006 and was tasked with "synchronizing the content and tone of Israel's message in subsequent military theatres" (Kuntsman and Stein 2010).
} 
Israeli website ever, attracting over 2 million views by the end of the assault (Anderson 2009). In tandem with the YouTube channel Israeli officials delivered private briefings to international bloggers and maintained personal video blogs. "In testament to the efficacy of the image, Israel mounted video cameras at the Kerem Shalom crossing in order to broadcast - online, in real time - its transfer of humanitarian goods into Gaza after the assault" (Kuntsman and Stein 2010). The short messaging website Twitter was used for the first time; the Israeli consulate in New York opened its own Twitter account two days after the start of the offensive, holding Twitter-based press conferences that were later lauded as having "revolutionized Israeli diplomacy" (Shamir 2009). But some of the fiercest efforts made by Israel were in the domain of popular internet usage. In an effort to stem 'anti-Israel sentiment', the Foreign Ministry "recruited undercover volunteers to deliver the state-sponsored war message to the Internet (sic) public through the informal language of the "talkback"" (Kuntsman and Stein 2010). The campaign focused on European websites, where audiences were thought to be particularly hostile to Israel. This project was formally added to the state budget in 2009 under the rubric "internet warfare team." In the words of the deputy director of the Foreign Ministry's hasbara department Mr Sihturman: "They will speak as net surfers and as citizens, and will write responses that will look personal but will be based on a prepared list of messages that the Foreign Ministry developed" (quoted in Cook 2009). These PR measures were deployed alongside the more explicitly violent bombing of Palestinian television and news stations throughout Gaza: this time Israel was taking no chances.

\section{Of victims and perpetrators}

Two messages were central to Israel's visual representation of the assault and they can be summarized by a simple typology: 'it's their fault, not ours' and its corollary: 'they started it'. 
Recycling old tropes of Israeli-Jewish victimhood, the core messages from the NID and the IDFSU were that Hamas broke the cease-fire agreements with Israel; that Israel's objective is the defence of its population; and that Hamas is a terror organization targeting Israeli civilians ${ }^{3}$ (Shabi 2009).

In September 2007 Gaza was officially declared a "hostile entity" by Israel's Security Cabinet. Lisa Bhungalia (2010: 349) has argued that the deeming of Gaza as a hostile entity constructs a conceptual framework based upon “an ontological distinction of 'us' and 'them': Gaza, the antagonistic, 'otherized' space...is set against the normalized, civilized space of Israel”. These orientalist tropes reduce the ongoing conflict to what she calls a post 9/11 "Manichean theatre comprised of humanity fighting the mujahideen, the besieded verses the barbaric". What kind of people inhabit a space which has been designated "hostile"? The naming of territory is simultaneously a demarcation of the population who live there; that which appears as terroristic and hostile is simultaneously that which can - must even - be contained or, in the last resort, eliminated. The crucial thing here is that Israel is always and already the victim and Gaza and Hamas are always-already the perpetrators. The Israeli narrative establishes Israel as a besieged space, one which has been breached - unremittingly - by the others of Gaza. The narration of Israel as victim and the naming of Gaza as hostile are two faces of the same coin. Together they work to constitute every Israeli act as defensive. If Gaza is the aggressor then accordingly they started $i t$; Israeli action is prefigured as a response to (rather than an instigation of) violence. As Zizek has pointed out, actions taken on the part of Palestinians are prefigured as 'acts of terror', and cited as 'proof' that Israel is, in fact, dealing with terrorists. This paradox, he argues, "'is

\footnotetext{
${ }^{3}$ The concept of the civilian is an especially complicated one in Israeli society because Israeli military operations rely on the mobilization of thousands of reservists who "shift from civilians to soldiers in a day" (King 2006, cited in Gregory 2004). The question of 'who is a civilian?' turns not only on the question of 'what is a civilian?' but crucially also 'when is what a civilian?'.
} 
inscribed into the very notion of a 'war on terror' - a strange war in which the enemy is criminalized if he defends himself and returns fire" (cited in Bhungalia 2010: 356). The typology of Israel-as-victim/them-as-perpetrators is an important component within the "cultural resources and social systems through which images are interpreted and valued" (Campbell 2007: 361), which is to say that that these constructions underwrite and frame the ways in which audiences understand the conflict between Israel and Palestine. Israel, after all, is "only democracy in the Middle East" and in the western geo-political imagination it therefore follows that as "an island of freedom located in a region controlled by military dictators, feudal kings and religious leaders, Israel should receive unreserved support from western liberal states interested in strengthening democratic values around the globe" (Gordon 2004).

\section{Visual-legal performances}

But the narration of Gaza as a hostile entity is not only a broad geo-political trope. IDF visualities substantiate, rationalize and legitimize these claims at the level of the image so that they become quotidian assumptions in popular news discourse. IDF visuals reproduce Gaza (and its people) as hostile by making two simple yet problematic claims. First, their images are intrinsically true. Second, because they are intrinsically true they can be used to make and substantiate legal claims about the enemy. IDF visual claims are therefore simultaneously legal claims. 


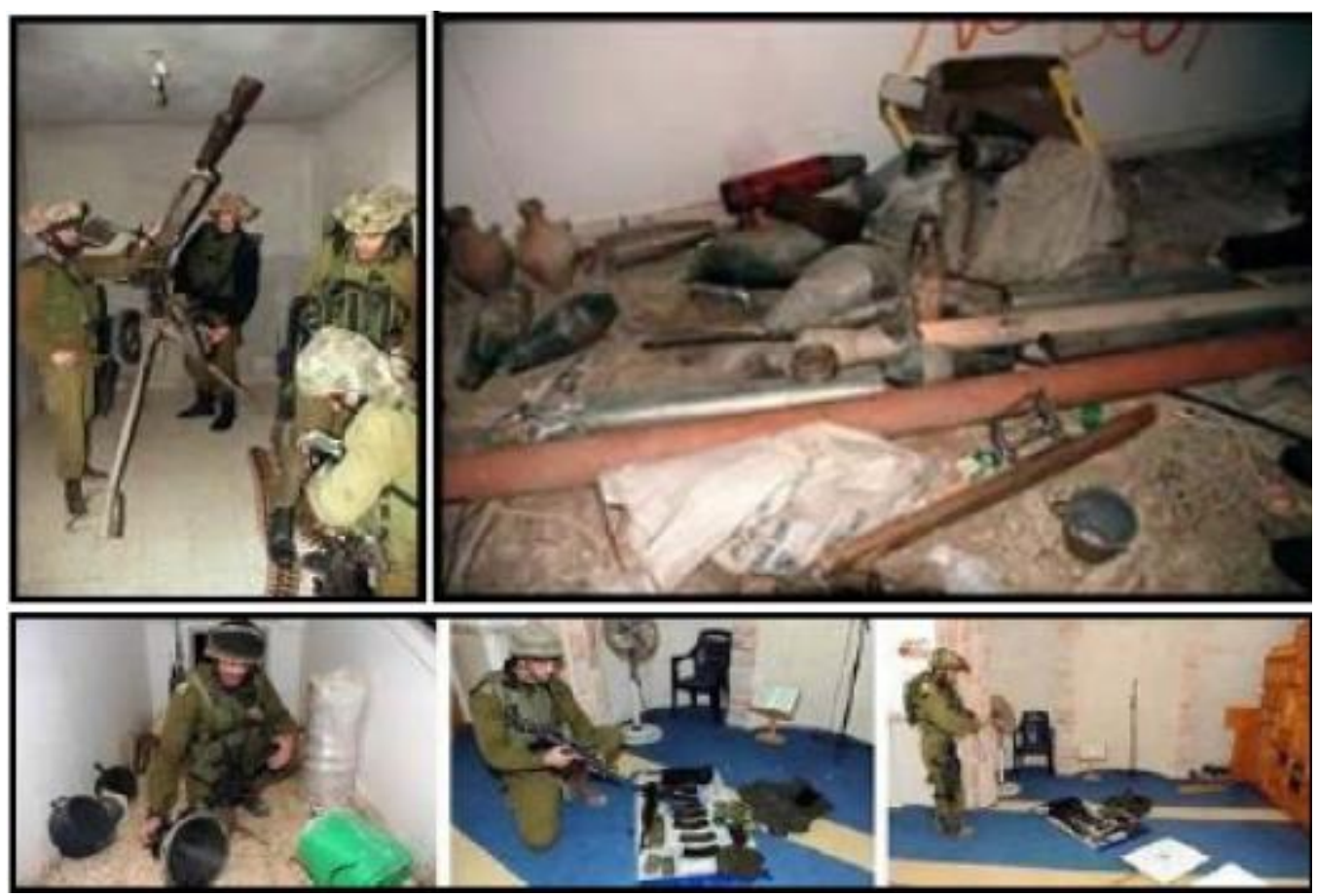

Figure 2: Hamas weapons. The original caption reads: "Weapons, including an anti-tank cannon, discovered in Jabaliya mosqueduring the Gaza Operation", source: Israeli Ministry of Foreign Affairs ${ }^{4}$

Hamas activities "spotted in the schoolyard" tell us why Israel fired on schools: because they fired from schools. The pointers tell us why Israel - “accidentally” - killed civilians: they deliberately - fire from civilian areas. Why could Israel not seamlessly distinguish terrorists from civilians? They don't wear uniform and therefore blend into the general population. They are Amitai Etzioni's (2010) “abusive civilians” par excellence. Where Israel regrets the loss of life on both sides, Hamas intentionally attacks innocent Israeli 'civilians" ${ }^{5}$ The plethora of weapons, the terrorists arsenal is paraded so we may witness its deathly scope, its unbearable intensity and visceral reality: these weapons exist (figure 2). Faces are revealed not to humanise but to demonstrate the inhumanity of those who kill at will, in the name of radical Islam and capital ' $\mathrm{T}$ ' Terrorism. They don't value life like we $d o^{6}$. These are performances of space that very much

\footnotetext{
${ }^{4}$ Pp. 60 IMFA 'Operation Cast lead' supra note

${ }^{5}$ See supra note 2.

6 This is a common sentiment implicit in the 'new wars' discourse and also amongst many Israelis. In an article published in the Israeli newspaper "Hassidic World" Yitzhak Ben-Zvi writes of the Arabs as "a cult of murderers,
} 
draw lines around the terroristic and barbaric space of the enemy. These are images that demonstrate the precarity of Israeli lives, the leakiness of the border and the perforations of space maintained by the terrorist other. The images perform Israeli space as constantly threatened and vulnerable (Figure 3). They present Gaza as a space saturated in terroristic backwardness, a space where hooded, faceless and thus unrecognisably human Hamas-figures forsake their own people for their radical fundamentalist cause. They use children and babies as human shields (figure 4); these are cowardly, immoral people inhabiting a corrupted and degenerate space. 'What kind of people' these images rhetorically enquire "launch rocket attacks from within densely populated areas near schools and protected U.N. Facilities"? What kind of commander uses "hospitals as bases of operations and ambulances for transport"? What kind of enemy "stores weapons in mosques" and "booby-traps entire civilian neighbourhoods so that an attack on one structure would devastate many others"? (IMFA 2009: 2).

savages, and a loathsome nation [...they] are a people similar to donkeys... they have a great desire to murder and are even worse than the Nazi enemy (quoted in Nahmias 2006) 


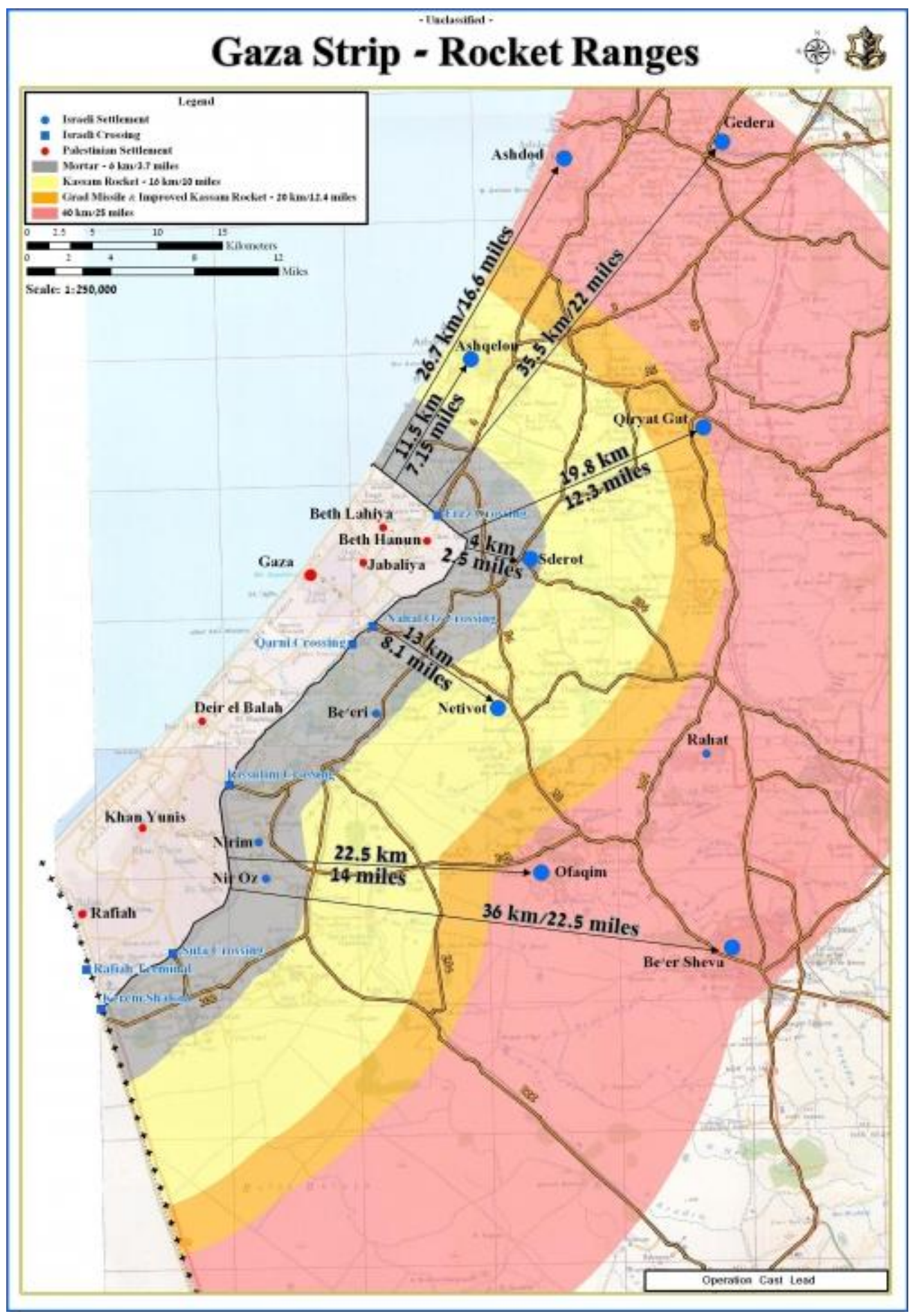

Figure 3: IDF Map of rocket ranges, source: IDF Spokesperson 


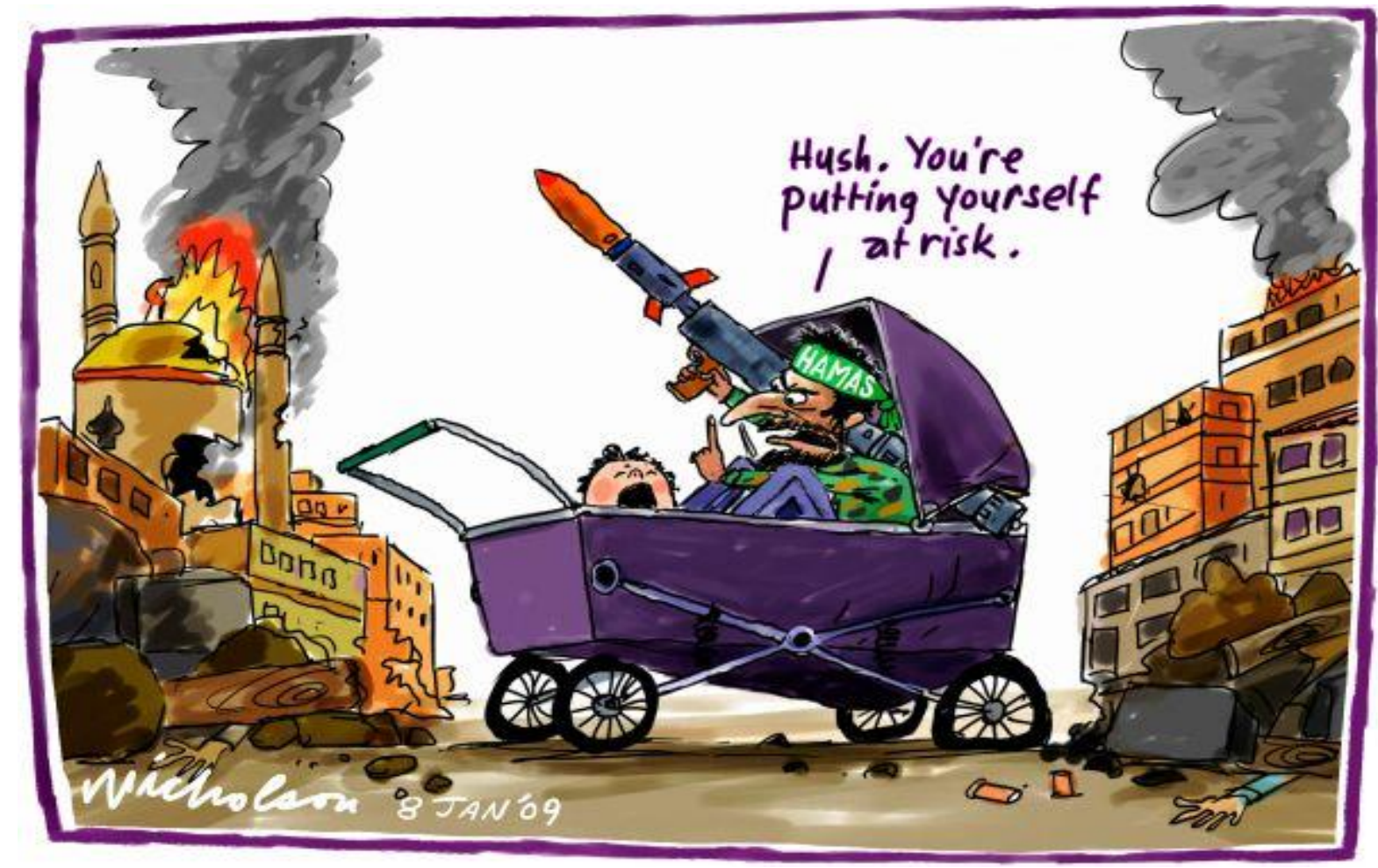

Figure 4. Hamas use of children as human shields, source: thediamongguru ${ }^{7}$

The answer? Them, not us. Israel abides by the law, Hamas breaches it. These visualities produce Israeli space and practice as resolutely different and irreconcilable to the practices and spaces maintained by Hamas and Gaza. The scripting and visualization of Gaza as a necessarily terroristic space performs the spectral figures that inhabit that space as dubiously human. Indeed, as Judith Butler (2004: 89) has warned us,

"If we assume that everyone who is human goes to war like us, and that this is part of what makes them recognizably human, or that the violence we commit is violence that falls within the realm of the recognizably human, but the violence that others commit is

\footnotetext{
${ }^{7}$ At: http://images.google.com/imgres?imgurl=http://4.bp.blogspot.com/_aKt4nP9jd8/SWrCd7xlf4I/AAAAAAAAFal/6LodWXQHTCU/s400/hush.bmp\&imgrefurl=http://thediamondguru.blogspot.co $\mathrm{m} / 2009 / 01 /$ israel-v-gaza-hamas.html\&usg=_KSdXo2gugvX7bQAFyvMy3NYvRl=\&h=279\&w=400\&sz=41\&hl=en\&start=0\&sig2=R605iJRjo1ESWUYY8YfZlw\&zoom=1\&tbnid=An5eBLPE3_6IM:\&tbnh=149\&tbnw=214\&ei=JsmcTPy2llamsQOyj63VAQ\&prev=/images\%3Fq\%3Dhamas\%2Bcartoon \%2Bhuman\%2Bshields\%2Bhush\%26hl\%3Den\%26biw\%3D1280\%26bih\%3D619\%26gbv\%3D2\%26tbs\%3Disch:1\&itbs $=1 \&$ iact=hc\&vpx=141\&vpy=93\&dur=101\&hovh=187\&hovw=269\&tx=122\&ty=57\&oei=JsmcTPy2 IlamsQOyj63VAQ\& esq=1\&page $=1 \&$ ndsp $=18 \&$ ved $=1 \mathrm{t}: 429, \mathrm{r}: 0, \mathrm{~s}: 0$
} 
unrecognizable as human activity, then we make use of a limited and limiting cultural frame to understand what it is to be human"

Israel's visual-legal performance commits to a Manichean dichotomy between what Butler calls the recognisably human and the dubiously human. Once this rhetorical manoeuvre has been completed the very barbarity and excessive lawlessness of the enemy other serves to legitimise Israel and the means of violence employed during the assault. It is no longer simply that what Hamas is doing is deemed illegitimate by Israel. Their illegitimacy is now performed in images and in videos so that we may witness, in real time and via the unquestionable truth of the camera, their inhuman acts, their use of human shields and their cowardly hiding. Without the visual scripting of Gaza as a terrorist entity, without the imaging of Israel as victim, without the satellite images of rocket launch sites, and without the display of Hamas weapons, Israel's claims would make little sense. The law is used to delegitimize the enemy while simultaneously legitimizing Israeli actions. What makes these visualities so compelling first and foremost is that they visualize legal 'truths', rendering often complex legal arguments transparent via the appeal to unmediated, disinterested objectivity. The most threatening claim made about the IDF in Gaza was that its actions were illegal and amounted to crimes of war $^{8}$. In this sense it became doubly imperative for Israel to articulate a legal defence and offense that were remarkably simple and clear and yet which could also be articulated and disseminated widely through popular visual media. The beauty of all this is in the coming together of the visual and the legal in a discourse of truth and immediacy.

Israel's claims do not have to be believed because they can be seen. The IDF videos posted on YouTube use indexical indicators that appeal to the intrinsic truth of images: "what we have

\footnotetext{
${ }^{8}$ This was the conclusion reached by the U.N. Fact-finding Mission in Gaza, commissioned by Sir Justice Richard Goldsone (see U.N. 2009) as well as a number of international NGO and human rights groups.
} 
behind me [on two television screens] is further evidence..."; "what this map proves is the way in which Hamas deliberately puts its own people directly in the line of fire..." "what you are about to see is actual footage taken from the cockpits of Israel aircraft that proves..." (IDF 2009). The images are speaking. It matters not what they say so much as whatever they claim is unquestionably true. They prove this by showing that. These rhetorical tricks appeal to the notion that seeing really is believing. But what is most interesting about these images is that without the apparatus of indexes, pointers, captions and voiceovers they simply make no sense. It is not obvious for example that the blurred figure in front of what we are told is a U.N. building is infact a Hamas operative, just as it is impossible to tell whether the video purportedly showing Hamas operatives loading a truck full of missiles is not actually footage of civilians loading a truck full of oxygen canisters ${ }^{9}$. Images are not disinterested but are recruited to make arguments. Israel is profoundly interested in these images not for what they intrinsically communicate but precisely because Israel has learnt to communicate through and for the image.

IDF images do not speak for themselves, but are spoken for. Images always demand interpretation and the IDF assist the interpretation of its images with captions, directives, and explanatory tags. These indexical pointers become crucial to help mobilise condemnation (or conversely, give cause for celebration) of the violence depicted in images, so as to generate the 'appropriate' response (Sliwinski 2004). The pointers and captions instruct us what to see and what to remember; multiple meanings are reduced to a single or narrow interpretation (Moller 2007): its' their fault, not ours because they are terrorists and they started it.

\footnotetext{
${ }^{9}$ On December 29 2009, the Israeli Air Force killed eight civilians who they thought were loading missiles onto a truck. In July 2009 Israel published an investigation into the incident, concluding that, "In fact, the truck was carrying oxygen tanks and not rockets" (IMFA 2009: 146).
} 


\section{Visual Economy}

Images circulate in what Deborah Poole has called a 'visual economy'. Poole argues that the idea of a visual economy is superior to the notion of visual culture because visual economy demands attention to the way "visual images [are] part of a comprehensive organization of people, ideas and objects" (Poole quoted in Campbell 2007: 361). In order to understand the significance of visuality in the production of geopolitics Campbell (2007: 357) draws from Poole and concludes that visual culture must recast as visual economy to "enable the constitutive relations of geopolitics and visuality to shift from the social construction of the visual field to the visual performance of the social field". Images, never discreet objects, are part of a wider political assemblage that is made possible by - and is productive of - relations of power. These relations of power regulate and organize images at three different levels; the site(s) and spaces of production; the circulation of images and; the cultural resources and social systems through which images are interpreted and understood. Elsewhere, Campbell (2004) argues that the visual performance of the social field is structured by what he calls 'economies of regulation'. Being aware of the complex ways in which images are subject to economies of production, circulation, consumption and endless regulation alerts us to the fact that "images do a lot of work: they visually perform the social field on which action can be made to occur, they testify to the conditions of the social field, and they can induce a responsibility in those concerned about the social field" (Campbell forthcoming, see also Keenan 2002). But the all important point remains: images cannot do this alone. Images enter social worlds and political contexts that exist prior to their shooting and circulation, and these contexts - be they geo-political, legal or economic - can determine what any image may (or may not) achieve. The single image "cannot testify to what is revealed through it, but must be attached to another image, another piece of information, another 
assertion or description, another grievance or piece of evidence, another broadcast, another transmitter. An image is only ever another statement in a regime of statements." (Azoulay 2009: 191) Conceptualising the visual field of Gaza in terms of a visual economy means that images cannot be isolated as discrete objects but have to be "understood as imbricated in networks of materials, technologies, institutions, markets, social spaces, affects, cultural histories and political contexts" (Campbell 2007: 361).

\section{'What the Arabs see'}

One of the most powerful counter-claims made in Palestinian coverage ${ }^{10}$ of the assault on Gaza was the representation of suffering and the display of dead bodies. Images of suffering, many of them graphic, reached an international audience and were found all over the (front) pages of international newspapers such as The Guardian, The Observer and The New York Times (see Campbell forthcoming). But what can these images achieve?

Many political practices rely on a techno-logic of the visual to validate their respective projects, and many rely on the circulation of abject imagery to illustrate and support their political claims (Moller 2007). The representation and communication of suffering is central to Palestinian identity (Allen 2009). Lori Allen (2009) and George Giacaman (2002) argue that suffering marks a particular moment in Palestinian history around the time of the First Intifada when Palestinians "discovered" human rights as the ideal language through which to make their voices heard. They are correct that the mobilization of suffering as a means of self-representation

\footnotetext{
${ }^{10}$ I take 'Palestinian coverage' to include professional and amateur journalists as well as citizens that were inside Gaza, reporting from a position sympathetic to the Palestinian cause and critical of Israel's assault. While this broad definition homogenizes what is undoubtedly a heterogeneous collection of perspectives, I use it because according to many reports a so called 'Palestinian perspective' was clearly present in the reporting of the assault. I hope to challenge the usefulness of the category in what follows.
} 
reached critical mass around that time, but Palestinian suffering is, of course, much older. Al Nakba, the catastrophe (1948), signalled the immediate forcible removal of 711,000 Palestinians from their homes and land. Suffering remains one of the few constants for a people subject to Israel's arbitrary and encroaching rule; violence and suffering has become normal, indeed increasingly normal since the Second Intifada (Allen 2008). In this way Palestinians have learnt to vie for empathy in what Bob (2002) has called a "global meritocracy of suffering in which all deserving causes attract international support”. Many feel that because suffering is an integral part of Palestinian life it should be represented in an unmediated fashion. Their argument is that the visceral nature of bodies and injury communicates better than anything else the infliction of pain and suffering by Israel. This is a common sentiment amongst Palestinians. Lori Allen (2009:161) for example, tells of how her friend Khader insisted on showing her images of mangled bodies and the aftermath of violent clashes from the Second Intifada. For Khader, images of suffering constitute irrefutable proofs of injustice: "the person who cares about humanity, it would affect them, and they could judge...let the world see and it will do something". If suffering is not seen, it is not known and if it is not known then there can be no catalyst for change.

Al-Jazeera coverage of the assault showed Palestinian suffering in all its unedited detail. Their network was the only international broadcaster with reporters on both sides of the border, in Israel and Gaza (Al Jazeera 2009). The fact that Al Jazeera had six reporters on the ground even before the assault had begun was doubly significant as numerous other international news outlets began to rely on them for their information, images and footage (Cohen 2009). Habib Battah (2009), freelance journalist and media analyst based in Beirut and New York claims that the images captured by Palestinian journalists were "often broadcast unedited". Typically: 
"The cycle begins with rooftop-mounted cameras, capturing the air raids live. After moments of quiet, thunderous bombing commences and plumes of smoke rise over the skyline. Then, anguish on the streets. Panicked civilians run for cover as ambulances careen through narrow alleys. Rescue workers hurriedly pick through the rubble, often pulling out mangled bodies. Fathers with tears of rage hold dead children up to the cameras, vowing revenge. The wounded are carried out in stretchers, gushing with blood. Later, local journalists visit the hospitals and more gruesome images, more dead children are broadcast. Doctors wrap up the tiny bodies and carry them into overflowing morgues. The survivors speak to reporters. Their distraught voices are heard around the region; the outflow of misery and destruction is constant"

Such was routine for the independent Palestinian journalists who lived the story they were reporting. Images of dead children and mangled bodies were commonplace; the suffering was laid bare for Arab audiences to see. The images and coverage of the assault by Al Jazeera demonstrate an unrelenting physical intimacy with death. Bodies were revealed in all their rawness, the emphasis on their "destroyed physiology was shown in a form" that according to Allen "accentuated that rawness" (2009 :171). A whole affective register and environment is created; families and friends weep and cry over dead bodies and crowds gather around to morn their lost ones, their Martyrs. The explicit coverage of the war by Arabic channels like Al Jazeera confirms Allen's observation that suffering and victimization become central to humanizing the Palestinian subject. Palestinian visualities imagine and appeal to an 'international community' via a politics of immediation. A benevolent audience is assumed to exist and Palestinian bodies in all their visceral reality become the visual vehicle through which Palestinians hope to prove that they are legible as the 'human' in human-rights and humanitarian discourse.

In order to answer what such visualities are able to achieve it is first necessary to distinguish between what U.K.'s Channel 4 News John Snow (2009) has claimed are "two versions of the assault on Gaza" The first, he argues "is the moderated account aired in the West; the other is the unexpurgated account of civilian deaths filmed in vivid close-up inside Gaza". 
Audiences are not pre-given but are constituted by and through discourse and as such the 'two versions' both respond to and reproduce audiences who already carry with them a series of assumptions, attitudes and values. But the question of what images might achieve relies on much more than who the audience are. There is also the question of how those images might be mediated, framed and regulated in the visual economy. While Snow's distinction between what the "Arab" world saw and what the "West" saw is useful, it leads him to a problematic conclusion. He claims that "as with every military conflict, the inevitable first casualty is the truth". Snow assumes that there is some irreducible and objective "truth" beneath the fog of war and in this context he is explicit that the "unexpurgated" Arab coverage provides such truth. This is an interesting counter to the claims made by Israel that their own account is the only true one. But by claiming that the "Western account" has been so reduced by the ban on journalists that the scale of protest has been dulled, Snow implies that if only "Western" audiences would have seen the "truth" (by which he means "wailing women running in the streets, carrying the wrapped remains of tiny children") protest would have been automatic. This is an extremely problematic assumption which overlooks the above conversation about how images are mediated, framed and regulated not only by Israel's media ban but by the visual economy and particularly the economies of regulation in our own media. If attention is shifted to focus on the visual economies of Gaza I suggest that Snow's 'two versions' actually come to resemble each other and end up producing a narrative that is not too dissimilar from the Israeli narrative.

\section{What we (don't) see}

Palestinians shared a hope that the world would see their suffering. But many western audiences do not like to see the worst of war and there has been a move toward filtering explicit content via the protocols of 'taste and decency'. Taste and decency involves the media regulating the representation of death and atrocity so that bodies "dissappear" - or rather, do not appear in 
the first place (Campbell 2004). The economies of taste and decency are entrenched today and examples abound. One of the most high profile cases recently was when the U.S. Senate barred news photographs of the flag-covered coffins of service members killed in Iraq (see Stolberg 2002). This is not an exceptional case but are the norm according to which much of the raw footage from Gaza was edited. Picture editor of The Independent, Sophie Batterbury wrote about how she handled some of the 300 images that reached her desk on the first morning of Israel's attack. She recalls a "number of images showing dead and dismembered bodies, some of which were relatively mild in tone and others which were so horrific that I couldn't look at them any larger than thumbnails" (quoted in Campbell forthcoming: 12). It was not that such images were not available: they were in abundance. In Campbells' analysis of the coverage of the war by the U.K.'s Guardian and Observer, he claims that only a handful of images showed dead and maimed bodies. In another example, editor Julian Rake recounts of the way in which Reuters edits footage and images before they sent them out to newspapers and news stations around the world. Rake defends a decision not to air the full footage of a burnt baby, five month old, being removed from the back of an ambulance by a doctor ${ }^{11}$ : "what we did was we showed, a sanitised if you like, yea a sanitised version...in my view putting that other stuff [the graphic footage] wouldn't have added to your understanding, to my understanding of what happened" (quoted in Channel 4 2009).

Yet 'sanitization' of such footage is never only about public understanding, but is productive of publics and public understanding. The shying away from the explicit that these examples demonstrate is at the same time a shying away from the most pressing issues of the day: life and death. If the unsanitized picture is a weapon for Palestinians then the editing of gore is also a kind of sanitization of the Palestinian cause. If missing limbs, severed heads and broken

\footnotetext{
${ }^{11}$ The full footage can be seen at: http://blip.tv/file/1679332/
} 
bodies cannot be seen, perhaps the dead just vanished. If seeing is believing, what about that which is not seen, is it rendered necessarily unbelievable? Numbers are easier to digest than explicit images of the body in pain, just as numbers of fallen soldiers are easier to digest than images of their coffins. The coffin bespeaks the body it holds; the body in severe pain bespeaks its unrepresentability, hence the discomfort it causes. There was possibly no 'need' for Reuters to send out such horrific and graphic footage just like there was no 'need' to print numerous images of dead Iraqi's in the British and U.S. press. At one level one might sympathise with the decision to edit such images. Images of suffering are not an injunction to action as is so often hoped; the problem of 'compassion fatigue' (Moeller 1999) is by now well documented. The compassion fatigue thesis argues that the abundant supply of imagery dulls our senses and creates a syndrome of communal inaction. It is also worth noting that the displaying of dead bodies partly reproduces the violence represented in the image, normalizing death and suffering. In this view the proliferation of images of "just more Palestinians dying" are read as naturalized and generalized statements of horror. The problem with this view is that it intersects all too closely with a discursive turn in the representation of war as something else other than the infliction of mass death and suffering. It also intersects dangerously with IDF visual narratives which erase images of death from war or construe death as necessary collateral damage in the fight of good against evil. In this way the turn toward 'taste and decency' is simultaneously a turning away not just from the realities of war but from a way of representing war that "we" in the west find excessive and voyeuristic.

In the end it is not only 'their' wars that are so different to our own but also the very way in which they represent their wars. Apparently the Arab world abandons "truth" in pursuit of "images of carnage and emotional narratives" (Fleishman and Rafei 2009). As the assault on 
Gaza wore on and such images proliferated on Arab news stations, the Jerusalem Post described the coverage as "voyeuristic, nearly pornographic". Something about Palestinian representational forms and its proximity to the graphic repulses not only the Jerusalem Post. As the Los Angeles Times would have it: "Al Jazeera and other Arab media outlets have grown more objective in reporting in recent years, but when it comes to the Palestinian-Israeli conflict, balanced coverage is often outweighed by pathos and narratives of funeral corteges proceeding amid the sounds of explosions" (Fleishman and Rafei 2009). Arab media outlets (all of them) just can't help themselves when it comes to this conflict. Such renderings of Arabic representational forms are used to denounce the authenticity and trustworthiness of "their" media; their proximity to death is framed as necessarily biased. As one commentator recently said of Al-Jazeera's coverage of Israel's illegal assault on the Mavi Marmara Aid Flotialla, "it was about as fair as cutting one leg off a chicken and sticking it in a fox-run" (Spencer 2010). Indeed, this was the sentiment of the Israeli state when two months after the assault on Gaza Israel launched a boycott of al-Jazeera, accusing it of "bias" because it had covered the Gaza incursion but not the Palestinian rocket attacks against the Israeli city of Ashkelon (BBC 2008). Yet all this is marked by a stunning irony: the IDF rely on precisely the same fiction that their images and footage are unmediated and are therefore true. The act of boycotting al-Jazeera on account of "bias" is a rhetorical act which elides the fact that Israeli coverage too is profoundly - necessarily - biased and mediated. That Israel went as far as to ban foreign press from Gaza sheds light on the contradictions and double-standards in the IDF narrative.

\section{Equivocating suffering, eliminating politics}

From time to time, the screen that insulated western audiences from Gaza was ruptured by photographs transmitted via email by Gazan photographers - unbearable images of severe 
harm to civilians (Azoulay 2009). Very few of these were printed in Israeli daily press ${ }^{12}$. But when these images did find outlet in international media they were blunted by two further economies of regulation.

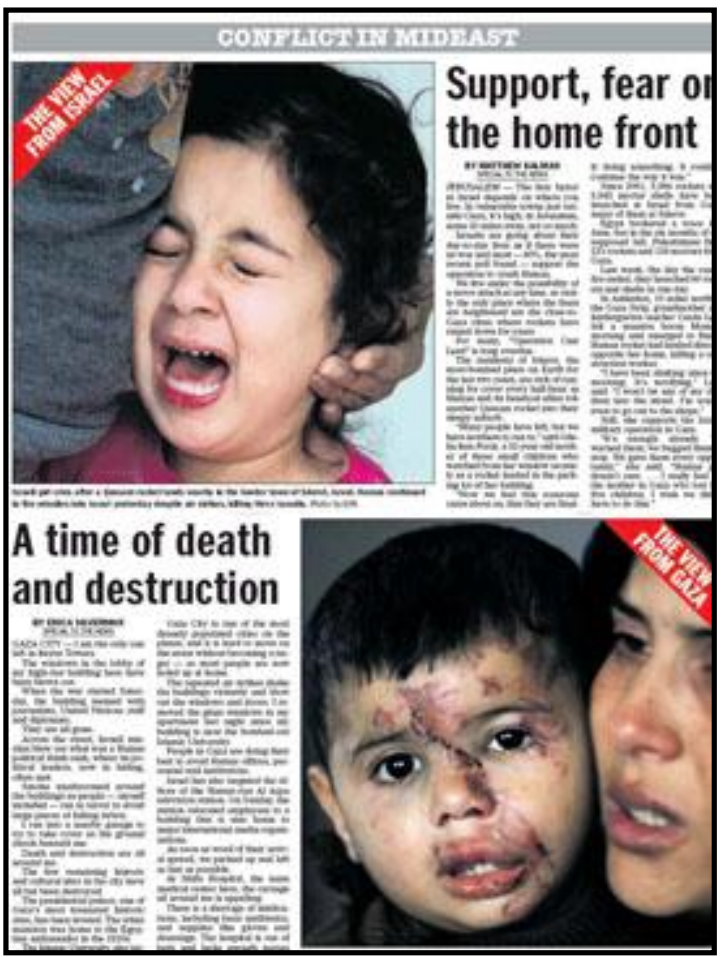

Figure 5. Washington Post Front Page, Source: Al Jazeera ${ }^{13}$

First, Palestinian suffering was often presented alongside Israeli suffering. The New York Times online ran a retrospective on Gaza entitled "Photographer's Journal: A War's Many Angles" 14 . Under the aegis of 'fairness' and 'objectivity' the feature comprised two sets of photographs, one from Israel taken by Moises Saman and the other from Gaza taken by Tyler Hicks. The photographers provide voiceover audio testimony that begins when the viewer views

\footnotetext{
${ }^{12}$ Gideon Levy cites an example that he claims was telling of the Israeli coverage of the assault on Gaza. On a single day during the assault around 200 Palestinians were killed. The following day no news could be found of their death on the front page of Israel's leading newspaper. Instead Yediot Ahronot ran a story on an Israeli dog killed by a

Kassam rocket. Scroll to page 16 and there were two lines about the Palestinian deaths. (Levy 2010; Hari 2010)

${ }^{13}$ The date is not given: image and story available online at: http://english.aljazeera.net/focus/war_on_gaza/2009/01/20091585448204690.html

${ }^{14}$ The full sets of images can be found at: http://www.nytimes.com/packages/flash/international/20090125PhotoJournal-Gaza-Israel/
} 
the first image. Flicking through the images one is compelled to feel compassion not only for the Palestinians but for Israeli's as well. Both sides bury their loved ones; both sides have their widows. Symmetries are established by bullet-holes and bombed out homes: destruction is wrought on both sides. A similar 'balance' was struck by the Washington Post who ran a front page story with images of two distraught children clinging to their mothers: On the left, a Palestinian mother who lost five children (figure 5). On the right an equal-sized picture of an Israeli woman who was "distressed by the fighting". The presentation of mutual suffering rhetorically produces the media as disinterested harbingers of truth. The BBC displayed this sentiment when it refused to give airtime to the Disasters Emergency Committee appeal for funds to aid Gaza. Director General Marc Thompson claimed that airing the appeal would pose a "danger for the $\mathrm{BBC}$ " because it "...could be interpreted as taking a political stance on an ongoing story". These editorial decisions discursively construct the media as apolitical while ironing over the differences between Israeli and Palestinian suffering.

What about the assault on Gaza was equal and symmetric? What about the reporting of war has ever been "objective"? In the NYT retrospective there is a strange absence of action in the Israeli set of images. It is particularly strange given that the positioning of Moises Saman's photographs reveal that he was embedded with the IDF at the time. As Lagerquist (2009: 88) points out: "Not a single one is shooting, loading a gun, or cleaning a tank barrel. Plumes of smoke across the border are pictured only distantly, one of them from some elevation, unfurling elegiacally from a remote, empty beach. It is as if some other army were in the process of killing fourteen hundred people". In 1991 the then Chief Spokesman for the IDF, Nachman Shai recommended the attachment of media teams to military units, a measure he assured would "have a definite impact on local and world opinion and, in the long run, will be to our benefit" 
(1998: 15). Embedding journalists would become official IDF policy. This is precisely why none of this can be construed as 'fair', 'unbiased' reporting. Journalists embedded on the front line construct a very partial way of seeing. Moises Saman's choice of location was not coincidental; he was based in the Israeli town of Ashkelon, one of the main towns that was receiving rocket fire from Gaza.

It is disingenuous to present Palestinian suffering alongside Israeli suffering under the aegis of objectivity because the scale and intensity of violence are incomparable. Israel launched a full-scale military assault on a largely (or wholly) defenceless civilian population. Numbers matter. Fourteen hundred Palestinians died. The number was eleven for Israel. The tactic of claiming objectivity renders the suffering of Palestinians illegible on its own terms. Palestinians can suffer only so far as and as much as Israelis are seen to be suffering. To show Israeli suffering as comparable to Palestinian suffering is a profoundly political act that is, as Major Avital Leibovich admits, "favourable to Israel" (quoted in Shabi 2009). We must resist such attempts to parallel Palestinian and Israeli suffering, not only because doing so draws a moral equivalence between the Israeli woman who is tired of war and the Palestinian woman who has lost all of her children (Figure 5), but because Palestinian suffering, identity and agency is subsumed by a generalized suffering of both sides.

Those pictoral representations of suffering that made it past the economies of taste and equivalence "reproduced" according to Campbell (forthcoming: 25) "a humanitarian subjectivity that is consistent with continued Israeli governance of the Occupied Territories" ${ }^{\prime 15}$. Campbell locates the efficacy of the ban at precisely the point at which the ban itself appears to fail, the point at which images find their way out of Gaza. Campbell argues that it is in these images that "we have the production of Palestinians as "humanitarian clients"" a category which "severely

\footnotetext{
${ }^{15}$ Ibid pp. 25
} 
limits their political agency regardless of the intentions of those who took or published the pictures" ${ }^{16}$. This leads him to the conclusion that although newspapers like (but not limited to) The Guardian might have thought the publication of photographs of personal and infrastructural devastation offered a critical perspective on the conflict, they actually represent Gaza as a humanitarian catastrophe which is both temporary and somehow beyond the political. Campbell is quite correct to assert that the humanitarian emergency that ensued during and after the assault was "neither an emergency previously unknown nor a condition beyond politics" (pp. 27). Rather, as Israeli Philosopher Adi Ophir (2009) has shown with such perspicacity, Israel has long governed Gaza by an "ongoing measured and calculated catastrophization": "the scope of destruction and the number of civilian casualties [in Gaza] are first and foremost a temporary change in the mode of catastrophization: airplane bombs are added to the closure, artillery shells go hand in hand with the cutoff of electricity and the destruction of the sewage system". Carefully managed disaster is not the exception in Gaza but the norm. Humanitarian framings, framings which both Palestinian and international coverage work within propagate the sense that the violence is temporary and exceptional, deflecting attention away from the fact that the exceptional has become normal and the temporary, permanent. Occupation bleeds into war and back again, but the audience cannot see this in the iconography of humanitarian disaster. Does peace follow war? It surely depends on how one defines those misleadingly oppositional terms.

\section{Exposing frames: violences within}

The problems of productively challenging Israeli visual representations are manifold. The Palestinian representational form of showing suffering is inadequate on at least two accounts. First, western media elide Palestinian suffering, either via direct censorship or by showing it

${ }^{16}$ Campbell pp24-5 
alongside Israeli suffering. But even when Palestinian suffering is seen it is necessary to ask how it is framed, which brings us to a second problem. Representational framings of Gaza as a hostile entity proscribe Palestinians as spectrally human; their lives cannot be grieved because ultimately they - the terrorists - brought the assault upon themselves by firing rockets and blowing themselves up. The pictoral representations which hope, precisely, to challenge this perspective end up re-locating Palestinian lives in a humanitarian catastrophe over which 'they' (the Palestinians and the audience) have little control. The Israeli occupation disappears from view and it is hoped that the war will come to a swift and peaceful end: when the dreadful images stop, then the dreadful acts they represent presumably come to an end too. 'Operation Cast-Lead' may have ended, but the suffering continues under an occupation which Israel refuses even to acknowledge, let alone to bear responsibility for under the international law of occupation.

If such a diagnosis looks dim, I would argue that it is representative of the situation in Gaza today. The U.N. enquiry headed by Sir. Richard Goldstone into war crimes in Gaza has yielded little in the way of actual change, still less by way of justice. U.S. veto power will ensure that the Goldstone Report and others like it will not make their way to the International Criminal Court. And even if they did, the broken U.N. Resolutions scattered throughout Israeli history point to the fact that Israel is in-fact above the law, not subject to it. No justice will be done as far as the law is concerned. Neither will concession be paid by Israel in terms of renewing the peace talks: at present settlement expansion looks set to continue, rendering the peace talks futile. The border restrictions may have been eased since the Mavi Marmara affair in May 2010, but Israel still retains effective control of Gaza's air, land and sea space. 
The IDF was well aware that damaging and sensitive images would get out of Gaza during and after the assault. It is worth asking whether this marks not so much an oversight as a worryingly sophisticated understanding by Israeli PR technicians of the ways in which visual economies work. Israeli visual representations combined the overt regulation of images via the ban, but they also relied upon the covert and unspoken regulations of the visual economy that would end up privileging the Israeli narrative over its counter narratives. But perhaps what the IDF continues to underestimate is the power of the visual archive to circulate, change and generate new meanings. In this spirit Judith Butler has asked what happens to the visual fields of war when "the mandatory framings become part of the story"; what if "there is a way to photograph the frame itself'? ${ }^{17}$ Was it not precisely a 'framing of the frame' that we saw in the image and footage of the journalists stranded atop the hill outside Gaza? Parash hill became infamous during the assault; journalists called it the "hill of shame". They choose this name because hundreds of Israeli civilians climbed the hill to watch the show of Gaza burning. They posed for other exalted Israeli's while making 'victory' signs for the camera (Figure 6). The story told through this image, and through others like it is that Israel does not believe in the freedom of press, that Israel does not want the world to see its punishment of Gaza. The IDF media ban becomes part of the story; the frame constructed and sought by the IDF is quite literally framed at the same time as a violent inflection of Israeli society is exposed. That which constituted the frame, he who organized our gaze is brought into view. It is at moments like this that we might realise what we have seen is not some balanced, even less objective, view of the assault. Rather, we see how our seeing has been regulated by a powerful state that is invested in perpetuating catastrophe in Gaza through a series of politicized and often dehumanizing frames.

\footnotetext{
${ }^{17}$ Butler 'frames of war' pp.71
} 


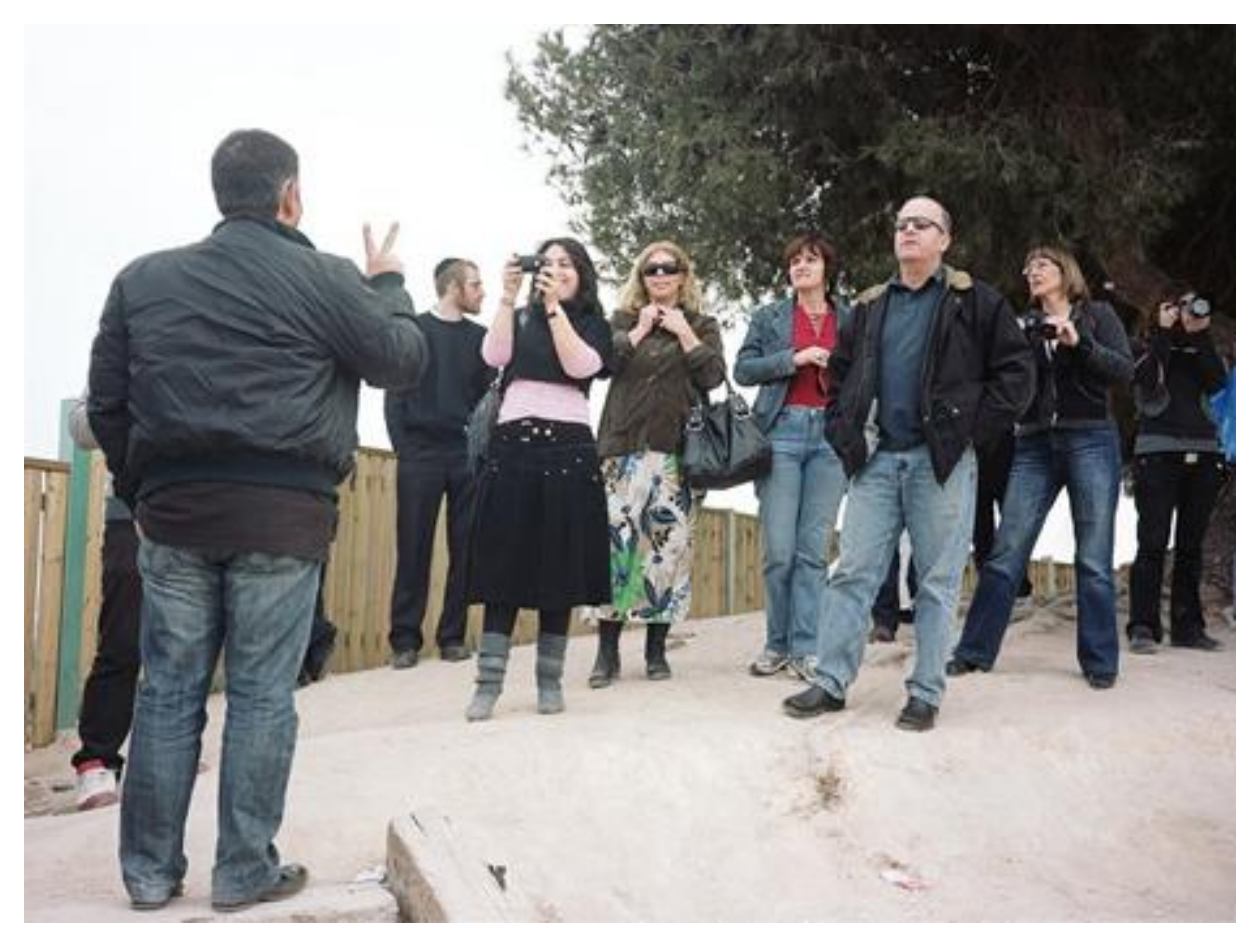

Figure 6. Israelis gathered on a hill near Gaza to see the "show" during one of the last days of bombing by the Israeli Air Force, January 2009, source: Ariella Azoulay, photograph by Miki Kratsman

Just as the assault on Gaza continues so the visual archive will continue to expand, circulate and sediment. There have already been renewed attempts by Israel to regulate the visual field since the assault on Gaza: in the attacks on the Mavi Marmara flotilla we witnessed the conjoining of the Israeli imagefare and warfare apparatus once again. "Everything" was filmed: the humanitarians attacked first, they had weapons, they were not actually humanitarians, but terrorists ${ }^{18}$. These are familiar tropes but I would suggest that today they are tropes which are being contested. I say this not only because the flotilla incident caused at least some momentary outrage in the international community. The Mavi Marmara flotilla was never going to reach Gaza, but that was not the intention of those on board. The aim was to expose the siege of Gaza, to reveal the truth that Gaza is still under the sovereignty of Israel. The violence of the Israeli state was exposed on that day, May 31 2010, as IDF boarded the Mavi Marmara and executed

\footnotetext{
${ }^{18}$ All these claims have been made by Israel and the IDF (see this video shot by the IDF which purportedly shows those aboard the Mavi Marmara using pre-emptory violence against IDF troops:http://www.youtube.com/user/idfnadesk\#p/a/u/0/gYjkLUcbJWo) See also IDF 2010
} 
nine Turkish passengers, some of them at point blank range. Could it not be that the Mavi Marmara incident provides at least a start point in answering the question raised by David Campbell: "how can the permanent emergency of catastrophization in Gaza be pictured?" There was no "war" on in Gaza that day; it was a day like any other, nothing exceptional: siege, struggle and survival. But what is war if not this? The visualities of the flotilla throw light on the fact that the catastrophes embodied in the siege of Gaza are permanent: everyday Gazan's are subject to Israeli rule and a calorie count custom-made by Israel's best. In 2006 Dov Weissglass, Chief Advisor to the then Prime Minister Areal Sharon, defended the blockade of Gaza thus: "the idea to put the Palestinians on a diet, but not make them die of hunger" (quoted in Urquhart 2006).

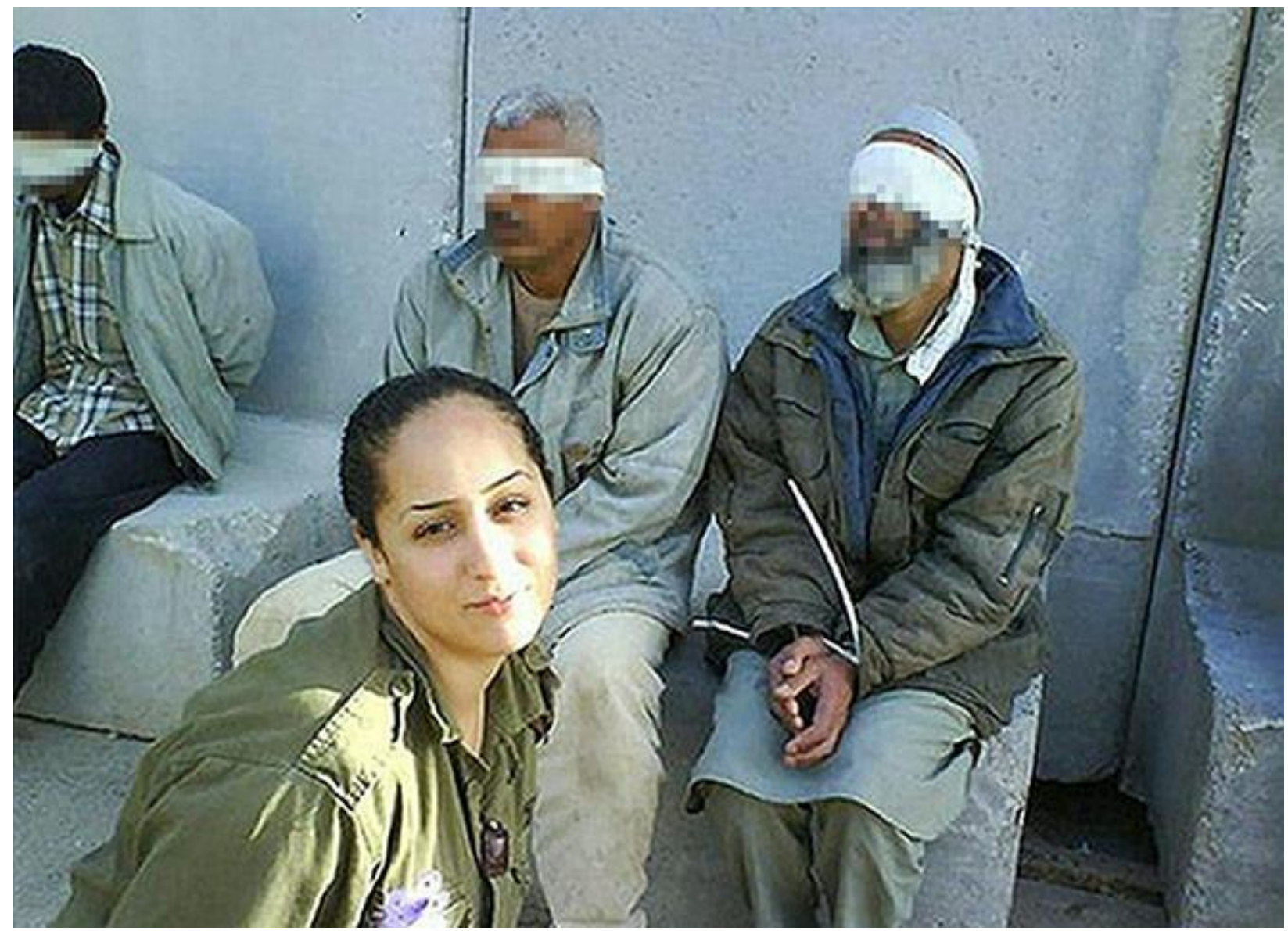


Figure 7. Eden Abergil sparked the outrage when she posted pictures of herself with Palestinian captives on her Facebook page, source: Guardian.co.uk., photograph by Getty Images/AFP

Israel's marked loss of control over the public narrative that followed the flotilla episode narrative has caused no small amount of consternation in Israel (Levy 2010). As one commentator put it, "we are being indisputably beaten hands down on the PR uses of this new technology [internet social media]. We may be a start up nation, but we are bricks and mortar communicators" (Mirzroch 2010). Just two months after the Flotilla killings and Israel and the IDF were back in the news, this time for a series of photos uploaded to Facebook by a former IDF soldier. The pictures showing Eden Abergil posing in-front of blindfolded Palestinian prisoners under the caption 'best time of my life' "raised a storm" in Israel and beyond (see figure 7). In the exposé that followed, Israeli newspapers reported on the prevalence of this digital activity. Haaretz news ran the headline 'Facebook photos of soldiers posing with bound Palestinians are the norm' alongside a series of images depicting IDF soldiers striking various poses next to dead or gagged Palestinians. One does not have to view the whole series to realise that these photographs bear some terrifying similarity to those of the torture in Abu Ghraib. The photographs of Abu Ghraib revealed that violence in the name of civilization reveals its own barbarism (Butler 2009: 93). Is not a kind of barbarism framed in Israel's own visualities? Does the violence dealt out to Gaza, to the Mavi Marmara and repeated everyday in Gaza not speak of a profoundly violent state? The loss of control Israel so fears is already in the past. As the visual archive circulates so Israel has become its own worst enemy. 


\section{References}

Al Jazeera English (2009) 'Focus on Gaza', Al Jazeera Online at:

http://english.aljazeera.net/programmes/general

Allen, L. (2008) Getting by the occupation: How violence became normal during the second Palestinian intifada', Cultural Anthropology, vol. 23 (3): 453-487

Allen, L. (2009) 'Martyr bodies in the media: Human rights, aesthetics, and the politics of immediation in the Palestinian intifada', American Ethnologist, vol. 36 (1): pp. 161-180

Anderson, N. (2009) 'Israel/Hamas battle goes Web 2.0', January 5, at:

http://arstechnica.com/web/news/2009/01/israelhamas-battle-goes-web-2-0.ars

Azoulay, A. (2008) The civil contract of photography, London: Zone Books

Battah, H. (2009) 'In the US, Gaza is a different war', Al Jazeera, 7 January, at:

http://english.aljazeera.net/focus/war_on_gaza/2009/01/20091585448204690.html

BBC (2008) 'Israel accuses al-Jazeera of bias' BBC Online, March 12, at:

http://news.bbc.co.uk/2/hi/7292676.stm

Bhungalia, L. (2010) 'A liminal territory: Gaza, executive discretion, and sanctions turned humanitarian', GeoJournal, vol. 75: pp. 347-357

Bob, C. (2002) 'Merchants of Morality', Foreign Policy, 129. at:

http://www.alternet.org/story/12669/

Butler, J. (2004) Precarious Life: The Powers of Mourning and Violence, London: Verso

Butler, J. (2009) 'Torture and the ethics of photography' in Frames of War, London: Verso

Campbell, D. (2004) 'Horrific Blindness: Images of Death in Contemporary Media' Journal for Cultural Research, vol. 8 (1): pp 55-74

Campbell, D. forthcoming 'Constructed visibility: photographing the catastrophe of Gaza', unpublished, at http://www.david-campbell.org/wpcontent/documents/Constructed_Visibility.pdf

Channel 4 (2009) Unseen Gaza, Dispatches documentary, January 22, for further info see: http://www.channel4.com/programmes/dispatches/episode-guide/series-6/episode-3

Chouliaraki, L. (2009) 'Witnessing war: economies of regulation in reporting war and conflict', The Communication Review, vol 12 (3): pp. 215-226. 
Cohen, N. (2009) 'Few in U.S. See Jazeera's Coverage of Gaza War' New York Times, 11 January, http://www.nytimes.com/2009/01/12/business/media/12jazeera.html

Coker, C. (2004). The future of war: The re-enchantment of war in the twenty-first century, London: Blackwell

Fleishman, J. and R. Rafei (2009) 'Arab media portray Palestinians as courageous victims', LA Times, January 8, at: http://articles.latimes.com/2009/jan/08/world/fg-arab-media8

Etzioni, A. (2010) 'Unmanned aircraft systems: the moral and legal case', Joint Forces Quarterly, vol. 57 (2 ${ }^{\text {nd }}$ quarter): pp. 66-71

Giacaman, G. (2002) 'Perspectives on Civil Society in Palestne'. Paper presented at a conference on PNA-NGO relations held by the Welfare Association. Ramallah, February 14-16, transcript at: http://www.muwatin.org/george/welfare.html

Gordon, N. (2004) 'Most Israelis Don't Believe It (or Support It): The Only Democracy in the Middle East?’ Counterpunch, February 3, at:

http://www.counterpunch.org/gordon02032004.html

Gregroy, D. (2010) 'Seeing Red: Baghdad and the event-ful city' Political Geography, vol. 29: pp $266-279$

Gregory, D. (2006) The Death of the Civilian?', Environment and Planning D, vol. 24 (5): 633638

IDF (2010) 'IDF forces met with pre-planned violence when attempting to board flotilla', May 31. at:

http://www.mfa.gov.il/MFA/Government/Communiques/2010/Israel_Navy_warns_flotilla_31May-2010.htm

IDF (2009) Spokesperson Youtube Channel, at: http://www.youtube.com/user/idfnadesk\#p/u

IMFA (2009) 'The Operation in Gaza: Factual and Legal Aspects' State of Israel, July, at: http://www.mfa.gov.il/NR/rdonlyres/E89E699D-A435-491B-B2D0-

017675DAFEF7/0/GazaOperation.pdf

Kaldor, M. (2006) New and old wars: organized violence in a globalized era (second edn.), Cambridge: Polity Press

Keenan, T. (2002) 'Publicity and Indifference (Sarajevo on Television)' PMLA 117 (1): pp. 104116

King, L. (2006) 'Israel's reservists shift from civilians to soldiers in a day' Los Angeles Times, 24 July, at: http://articles.latimes.com/2006/jul/24/world/fg-reservists24 
Kuntsman, A. and Stein, R.L. (2010) 'Another war zone: social media in the Israeli-Palestinian conflict', MERIP, September, at: http://www.merip.org/mero/interventions/steinINT.html\#_edn6

Lagerquist, P. (2009) 'Shooting Gaza: Photographers, photographs and the unbearable lightness of war' Journal of Palestinian Studies, vol. 38 (3): pp. 86-92

McDonald, F., K. Dodds, and R. Hughes (Eds.). (2010). Observant states: Geopolitics and visuality, London: I.B. Tauris

Mirzoch, A. (2010) '\#FreeHasbara', Jerusalem Post, May 31, at:

http://www.jpost.com/Opinion/Op-EdContributors/Article.aspx?id=176949

Moeller, S. (1999) Compassion fatigue: how the media sell disease, famine, war and death, New York: Routledge

Moller, F. (2007) 'Photographic Interventions in Post-9/11 Security Policy', Security Dialogue, vol. 38 (2): Pp. 179-196

Münkler, H. (2005) The new wars, Cambridge: Polity Press

Ophir, A. (2009) Reflections on Gaza from Tel Aviv, Zcommunications, January 11, at: http://www.zcommunications.org/reflections-on-gaza-from-tel-aviv-by-adi-ophir

Poole, D. (1997) Vision, race and modernity: A visual economy of the Andean image world, Princeton: Princeton University Press.

Shabi, R. (2009) 'Special spin body gets media on message, says Israel' The Guardian, 2 January, at: http://www.guardian.co.uk/world/2009/jan/02/israel-palestine-pr-spin

Shai, N. (1998) 'The Spokesperson-In the Crossfire: A Decade of Israeli Defense Crises from an Official Spokesperson's Perspective', Discussion Paper D-29 July, the Joan Shorenstein Center at Harvard University

Sliwinski, S. (2004) 'A painful labour: responsibility and photography', Visual Studies, vol.19(2): pp. 150-162

Snow, J. (2009) 'War, from a distance', The Independent, January 19, at:

http://www.independent.co.uk/news/media/tv-radio/gaza-war-from-a-distance-1419147.html

Sontag, S. (2003) Regarding the Pain of Others, New York: Farrar, Straus \& Giroux 
Spencer, R. (2010) 'Gaza flotilla raid and press bias: Who to (dis)believe?' The Telegraph, June 2, at: http://blogs.telegraph.co.uk/news/richardspencer/100041870/gaza-flotilla-raid-and-pressbias-who-to-disbelieve/

Stolberg, S.G. (2004) 'Senate Backs Ban on Photos Of G.I. Coffins', NY Times, June 22, at:http://www.nytimes.com/2004/06/22/us/senate-backs-ban-on-photos-of-gi-coffins.html

Urquhart, C. (2006) The Guardian Gaza on brink of implosion as aid cut-off starts to bite, 16 April, at: http://www.guardian.co.uk/world/2006/apr/16/israel. visual culture. London: I.B. Tauris. 